\title{
Influence of Farm Inputs Subsidy on Agricultural Yields by Small Scale Farmers in Alego Usonga Sub-County, Siaya County, Kenya
}

\author{
E. Ambajo ${ }^{1 *}$, C. Olweny ${ }^{1}$, W. Akuno ${ }^{1}$ \\ ${ }^{\mathrm{T}}$ School of Agricultural and food Sciences, Jaramogi Oginga Odinga University of Science and Technology, P.O. Box \\ 210-40601, Bondo, Kenya
}

\author{
*Corresponding Author
}

E. Ambajo

\section{Article History}

Received: 07.03.2021

Accepted: 10.04 .2021

Published: 17.04.2021

\begin{abstract}
Agricultural subsidies have been provided by the Kenyan government to farmers since 2004 in order to increase their outputs thereby improving the economic viability of small-scale farmers and improving food security Access and use of farm inputs in Alego Usonga is wanting as certified seeds and fertilizers are very expensive and out of reach for most farmers in the study area. This study examines the influence of farm inputs subsidy on yields of small holder farmers in Alego Usonga sub-county in Siaya County. The aim of this study is determining how inputs subsidies influence yields of small holder farmers in the study area. The study targeted 317 beneficiary farmers under the government's subsidy programme in Alego Usonga Sub County. Simple Random Sampling was then used to pick the final samples from the population strata. The instruments for data collection were observation, interview schedule, key informant guide and a structured questionnaire. Data were analyzed using the Statistical Package for Social Science (SPSS) computer program. Quantitative data was analyzed using simple statistics like frequency distribution tables and percentages, while narrative analysis was done using chi-square test for independence, spearman rank correlation to test the nature of the correlation between two variables and logistic regression model. The key findings showed that $55.5 \%$ of participants were female while $44.5 \%$ were male. Majority $62.1 \%$ of the participants agreed to have benefited from input subsidy. $61.5 \%$ of the participants agreed that fertilizers subsidy improve crop production. Finally, the study concluded that indeed input subsidy increase yields of small holder farmers.
\end{abstract}

Keywords: Agricultural subsidies, economic viability, farmers, food.

\section{INTRODUCTION}

Agricultural sector provides a strong and vibrant socio-economic pillar in development. Most governments subsidize agricultural sector inputs in order to improve the socio-economic viability of farming and ensure national food security [1]. Agricultural input subsidies were common in poor rural economies in the 1960s and 70s, but conventional wisdom deemed them ineffective by the 1980s and 90s [2]. However, in recent years, there has been a resurgence of interest and investment, mainly in Africa, in so-called 'smart subsidies', which seek to maximize the multiple benefits of subsidies to different stakeholders while minimizing their distortionary effects on inter alia efficient commercial market operation and development [3]. Over 80 percent of the population, especially living in rural areas derives their livelihoods mainly from agricultural related activities Kenya Agricultural Research Institute, 2012. While the Sustainable Development Goal (SDG) on hunger target is within reach in other parts of the world, there is however insufficient progress in sub-Saharan Africa (SSA) which carries the majority of world's most hungry people [4]. A study done by Crawford et al., [5], revealed that Sub-Saharan Africa applied the least rates of fertilizer (9 kg/ha) among the other regions of the world's average of $102 \mathrm{~kg} / \mathrm{ha}$ in 2003. This is no surprise given that farmers on their own in sub-Saharan Africa use less fertilizer as compared to farmers of other regions leading to low food output Minde et al., 2008 [6]; Tiba, 2009 [7]. Due to poorly developed infrastructure, the costs of transporting inputs to remote areas, particularly in landlocked countries, are very high. Banful [8] suggests that around 50\% of market fertilizer prices across Sub Saharan Africa (SSA) can be attributed to transaction costs compared with e.g. $20 \%$ in Thailand. Subsidies could only be effective under certain conditions such as complementing them and offering implementation support [9]. China, Malawi and some green revolution member countries are a few that have used subsidies effectively [10]. A major global concern

Copyright ( 2021 The Author(s): This is an open-access article distributed under the terms of the Creative Commons Attribution 4.0 International License (CC BY-NC 4.0) which permits unrestricted use, distribution, and reproduction in any medium for noncommercial use provided the original author and source are credited. 
is how to speed up and sustain the rate of adoption of technologies for increased agricultural production [11]. While findings of low levels of technology adoption by smallholder farmers is well documented, few studies have attempted to explain the reasons for the low rate of adoption [12], particularly among smallholder systems. Agricultural productivity can be increased and sustained through sustainable adoption of modern agricultural technologies [13]. The Kenya government goal of food self-sufficiency has not been attained since the late seventies despite various intervention programmes and policy pronouncements to reform the sector [14]. Majority of households in Kenya still remain food insecure. Estimates in 2013 indicated that over 10 million people were food insecure in Kenya, majority of them living on food relief and other social support programmes [15] due to inadequate agricultural production attributed to low agricultural technology adoption. Access to farm inputs has remained a challenge in Alego Usonga Sub County in Siaya County, which is the focus of the study though it has received farm inputs subsidy together with adequate extension services, low yields are experienced, leading to food deficits for close to seven months in a year forcing the residents to rely on food imports from outside the county. This has necessitated high food prices and hunger due to limited access and affordability. The problem of food insecurity which is as a result of inadequate inputs use has led to malnutrition and hunger among target population. Inputs are costly and therefore un affordable to many farmers. This eventually led to low input use which will lead to low yields. Another problem is availability of varying qualities of farm inputs in the market making it difficult for farmers to get the right quality inputs leading to poor yields. Access and use of farm inputs is wanting as certified seeds and fertilizers are very expensive and out of reach for most farmers in the study area. Households are also incurring huge food bills due to the high food prices. In line with this, agricultural subsidies to increase farmer's productivity and incomes to enhance food safety were introduced by the government. However, despite these concerted efforts by both Government and communities, food shortage cases are still rife in many parts of the county. Hardly hit areas like Alego Usonga Sub County still experience intermittent food insecurity. The use and adoption of modern agricultural inputs and improved technologies are constrained by their high costs, unreliable distribution outlets, little technical knowledge on their use, application and maintenance equally affect adoption. Siaya County subsidizes the production of food crops in order to achieve sustained levels of availability. Farm inputs subsidy program is intended to boost agricultural productivity thus ensuring food availability and security however still there is low agricultural productivity among smallholder farmers in Alego Usonga Sub County in Siaya County. Lack of access to quality farm inputs has been considered as the major contributor to this scenario in the County.

\section{Methodology \\ Research Design}

The study was conducted through a survey, this is a research design used to investigate population by selection of samples to analyze and discover occurrences in order to provide numeric descriptions of some part of the population and to describe and explain events as they are, as they were [16]. This is the most suitable for rapid data collection for this study. The descriptive survey was used to observe and describe the behavior of the subject without influencing them [17].

\section{Target Population}

The study targeted 1878 farmers engaged in crop farming in the six wards namely; Usonga, West Alego, Central Alego, South East Alego, Township and North Alego in Siaya County that received the government free supplied input subsidies of 50Kgs bag of CAN fertilizer, $50 \mathrm{Kgs}$ of DAP fertilizer and $10 \mathrm{Kgs}$ of certified maize seeds and farmers who received government subsidized NCPB fertilizer vouchers in 2015 Ministry of Agriculture report, 2015.

\section{Sample Size}

A sample is a small proportion of population selected using a predetermined procedure [18]. The study utilized a sample size of 317 based on the Krejcie and Morgan sample size determination table and as cited by [19] a target population of 1878 farmers gave a sample size of 317 .

\section{Sampling Procedure}

The sample was drawn from the target population of 1878 farmers. Since the target population was not homogeneous and the purpose of sampling happens to be to estimate the population value of a certain characteristic, then proportionate stratified sampling was used to obtain a representative sample of farmers from each region benefitting from government's subsidy programme. This method increases statistical efficiency and ensures that each farmer benefitting from government's farm subsidy program has a chance of being included in the sample [20]. Total samples of 317 participants were randomly chosen from the population 1878 for the purpose of this study. Proportional allocation method was used to keep the sizes of the samples from the different strata proportional to the sizes of the strata. If $P$ represented the proportion of population included in stratum $i$, and $n$ represented the total sample size, the number of elements selected from stratum $I$ was $n . P_{i}$. With the sample size (n) of 317 to be drawn from a population size (N) of 1878 which is divided into six strata of size ${ }_{N} 1_{=136, N} 2_{=322, N} 3_{=309, N} 4_{=463, N} 5_{=331}$. Simple random sampling was then used to pick the samples from each stratum. With the defined population of 136,322,309,463,331 and 317 farmers, and the 
proportionate representative sample of 23,54,52,78,56 and 54 for stratum 1,2,3,4,5 and 6 respectively. A complete list of each stratum population was randomly generated for interviews.

\section{Instrumentation}

Questionnaires, interview schedules and focused group discussion guides were used to collect the intended primary data. Secondary data was collected from journals and reports from the Ministry of Agriculture Livestock and Fisheries Development as well as agriculture sector stakeholders in the study area.

\section{Data Analysis}

Data was collected and analyzed using Statistical package for social sciences (SPSS) version 19. Data entry started immediately after receiving questionnaires from the respondents the information gathered was then summarized, tabulated and coded to facilitate analysis and ensure both accuracy and relevance of the analysis [21]. The data was analyzed using both quantitative and qualitative techniques. Quantitative data was analyzed using simple statistics like frequency distribution tables and percentages, while narrative analysis was used to analyze qualitative data in order to determine the effect of the components of the independent variable on the dependent variable, agricultural productivity. The suitable statistical techniques embraced in this study include chi-square test for independence, spearman rank correlation to test the nature of the correlation between two variables and logistic regression model.

\section{RESULTS}

\section{Use of Fertilizer}

The researcher sought to find out how many of the respondents do use fertilizer in their activities as well check its effect and relationship with the yield.

Table 3.1: Fertilizer Use

\begin{tabular}{|c|l|l|l|l|l|}
\hline \multicolumn{2}{|c|}{} & Frequency & Percent & Valid Percent & Cumulative Percent \\
\hline Valid & No & 39 & 12.3 & 12.3 & 12.3 \\
\cline { 2 - 6 } & Yes & 278 & 87.7 & 87.7 & 100.0 \\
\cline { 2 - 6 } & Total & 317 & 100.0 & 100.0 & \\
\hline
\end{tabular}

From the findings in Table 3.1 below, it's clear that majority of the respondents $(87.7 \%)$ do use fertilizer in their various activities.

Further analysis on its effect on the yield of small-scale farmers was performed.

Table 3.2: Chi-Square Tests

\begin{tabular}{|l|l|l|l|l|l|}
\hline & Value & df & Asymp. Sig. (2-sided) & Exact Sig. (2-sided) & Exact Sig. (1-sided) \\
\hline Pearson Chi-Square & $44.694^{\text {a }}$ & 1 & .000 & & \\
\hline Continuity Correction $^{\mathrm{b}}$ & 41.029 & 1 & .000 & & \\
\hline Likelihood Ratio & 31.006 & 1 & .000 & & .000 \\
\hline Fisher's Exact Test & & & & .000 \\
\hline
\end{tabular}

The findings in Table 3.2 below show that there is significant relationship between the use of fertilizer and yield [22]. Further analysis in Table 3.2 reflects that there a positive and significant relationship between the use of fertilizer as an input subsidy and the yield. This implies that there is an increase in the yield with an increase in the use of fertilizer. Darko, \& Ricker-Gilbert [23], concluded that farmers prefer subsidized farm inputs such as fertilizers hence it will positively impact on the farm produce for the farmers.

Dorward \& Chirwa [24] reports that increasing input use subsequently increases the land and labor productivity and enhances food security for poor households through an increase of earnings and reduced food prices [25]. Food security indicators show that most of the households run out of adequate food supply from own production before the next harvesting season but a report by Dorward et al., [26] showed that households had 8\% improvement in food security after initialization of a subsidy program. According to Abubakari \& Abubakari [27], educating farmers about any subsidy of farm inputs will greatly influence their knowledge and need to use them; therefore, this will lead to an increase in farm outputs. 
Table 3.3: Symmetric Measures

\begin{tabular}{|c|c|c|c|}
\hline & & Value & Approx. Sig. \\
\hline \multirow[t]{2}{*}{ Nominal by Nominal } & Phi & .375 & .000 \\
\hline & Cramer's V & .375 & .000 \\
\hline \multicolumn{2}{|c|}{$\mathrm{N}$ of Valid Cases } & 317 & \\
\hline \multicolumn{4}{|c|}{ a. Not assuming the null hypothesis. } \\
\hline \multicolumn{4}{|c|}{ b. Using the asymptotic standard error assuming the null hypothesis. } \\
\hline \multicolumn{4}{|c|}{ c. Correlation statistics are available for numeric data only. } \\
\hline
\end{tabular}

\section{Awareness of Fertilizer Subsidy}

Despite the use of fertilizer by majority of the respondents as seen in the above findings, it's clear that most of them were also aware of existence of fertilizer subsidy in the region [28]. This might have also facilitated in increase in usage.

Table 3.4: Government Subsidy

\begin{tabular}{|c|l|l|l|l|l|}
\hline \multicolumn{2}{|c|}{} & Frequency & Percent & Valid Percent & Cumulative Percent \\
\hline Valid & No & 55 & 17.4 & 17.4 & 17.4 \\
\cline { 2 - 6 } & Yes & 262 & 82.6 & 82.6 & 100.0 \\
\cline { 2 - 6 } & Total & 317 & 100.0 & 100.0 & \\
\hline
\end{tabular}
other.

The findings in Table 3.4 shows that the state of being aware had a positive impact to the yield in one way or the

Awareness of fertilizer subsidy had a positive and significant relationship with yield of small-scale farmers.

Table 3.5: Symmetric Measures

\begin{tabular}{|c|c|c|c|}
\hline & & Value & Approx. Sig. \\
\hline \multirow[t]{2}{*}{ Nominal by Nominal } & Phi & .362 & .000 \\
\hline & Cramer's V & .362 & .000 \\
\hline \multicolumn{2}{|c|}{$\mathrm{N}$ of Valid Cases } & 317 & \\
\hline \multicolumn{4}{|c|}{ a. Not assuming the null hypothesis. } \\
\hline \multicolumn{4}{|c|}{ b. Using the asymptotic standard error assuming the null hypothesis. } \\
\hline \multicolumn{4}{|c|}{ c. Correlation statistics are available for numeric data only. } \\
\hline
\end{tabular}

The findings in Table 3.5 below show that, awareness of fertilizer subsidy had a positive and significant relationship with yield of small-scale farmers. This shows that increase in awareness of fertilizer subsidy leads to an increase in yield. According to Abubakari \& Abubakari [27], educating farmers about any subsidy of farm inputs will greatly influence their knowledge and need to use them; therefore, this will lead to an increase in farm outputs.

\section{Effect of Fertilizer on Land Use}

Table 3.6: Increase Land Use

\begin{tabular}{|c|l|l|l|l|l|}
\hline \multicolumn{2}{|c|}{} & Frequency & Percent & Valid Percent & Cumulative Percent \\
\hline \multirow{3}{*}{ Valid } & & 35 & 11.0 & 11.0 & 11.0 \\
\cline { 2 - 6 } & No & 125 & 39.4 & 39.4 & 50.5 \\
\cline { 2 - 6 } & Yes & 157 & 49.5 & 49.5 & 100.0 \\
\cline { 2 - 6 } & Total & 317 & 100.0 & 100.0 & \\
\hline
\end{tabular}

From the findings, it's found that the use of fertilizer had positive and significant attribution to yield of smallscale farmers. Despite that, the findings in table 3.6 below shows that majority of the respondents $(49.5 \%)$ concurs that it has greatly increase their land use [29].

\section{Awareness of seed subsidy}

The researcher sought to carry out analysis based on seed subsidy awareness and examine if it has influence on the yield of small-scale farmers. 
Table 3.7: Seed subsidy awareness

\begin{tabular}{|c|l|l|l|l|l|}
\hline \multicolumn{2}{|c|}{} & Frequency & Percent & Valid Percent & Cumulative Percent \\
\hline \multirow{3}{*}{ Valid } & & 1 & .3 & .3 & .3 \\
\cline { 2 - 6 } & No & 56 & 17.7 & 17.7 & 18.0 \\
\cline { 2 - 6 } & Yes & 260 & 82.0 & 82.0 & 100.0 \\
\cline { 2 - 6 } & Total & 317 & 100.0 & 100.0 & \\
\hline
\end{tabular}

From the findings in table 3.7 below, its vivid that majority of the respondents $(82.0 \%)$ were aware of existence of seed subsidy while minority were not informed of the same. Due to an increase in technology innovation in the world, people can now easily access information; therefore, farmers are well informed about any changes that happen in the ministry of agriculture [24].

Table 3.8: Symmetric Measures

\begin{tabular}{|l|l|l|l|}
\hline \multicolumn{2}{|l|}{} & Value & Significane(p-value) \\
\hline Nominal by Nominal & Phi & .195 & .002 \\
\cline { 2 - 4 } & Cramer's V & .195 & .002 \\
\hline N of Valid Cases & 317 & \\
\hline a. Not assuming the null hypothesis. \\
\hline b. Using the asymptotic standard error assuming the null hypothesis. \\
\hline c. Correlation statistics are available for numeric data only. \\
\hline
\end{tabular}

The researcher further examined if the awareness of seed subsidy had an impact on the yield of small-scale farmers. From the output of their analysis in table 3.8 below it clear that seed subsidy awareness has strong and positive relationship with the yield which was statistically significant at $\mathrm{p}=0.002<0.05$ hence increasing the awareness of seed subsidy to small-scale farmers is likely to contribute positively to increase in yield.

\section{Access to Seed Subsidy}

Despite being aware and its positive contribution to the yield of small-scale farmers, the researcher carried out analysis to find out if the farmers could access the subsidized seeds.

Table 3.9: Access to seed subsidy

\begin{tabular}{|c|l|l|l|l|l|}
\hline \multicolumn{2}{|c|}{} & Frequency & Percent & Valid Percent & Cumulative Percent \\
\hline Valid & No & 55 & 17.4 & 17.4 & 17.4 \\
\cline { 2 - 6 } & Yes & 262 & 82.6 & 82.6 & 100.0 \\
\cline { 2 - 6 } & Total & 317 & 100.0 & 100.0 & \\
\hline
\end{tabular}

From the analysis in Table 3.9, it reflects that majority of the farmers $(82.6 \%)$ could access subsidized seeds and this is what has greatly enabled them to increase their production.

\section{Awareness of issuance of farm logistics}

The researcher sought to know the state of awareness of farm logistics to small-scale farmers in the region and if this farm logistics were having an impact in the yield of these farmers.

Table 3.10: Farm Logistics awareness

\begin{tabular}{|c|l|l|l|l|l|}
\hline \multicolumn{2}{|c|}{} & Frequency & Percent & Valid Percent & Cumulative Percent \\
\hline \multirow{3}{*}{ Valid } & & 3 & .9 & .9 & .9 \\
\cline { 2 - 6 } & No & 38 & 12.0 & 12.0 & 12.9 \\
\cline { 2 - 6 } & Yes & 276 & 87.1 & 87.1 & 100.0 \\
\cline { 2 - 6 } & Total & 317 & 100.0 & 100.0 & \\
\hline
\end{tabular}

The findings are shown in Table 3.10 and it's clear that majority of the farmers $(87.1 \%)$ were aware of farm logistics in the regions. 
Further, the findings in Table 3.11 below shows that this awareness had a positive impact and it contribute positively and significantly $(\mathrm{p}=0.001<0.05)$ to the yield of these farmers. Hence an increase in awareness is likely to lead to an increase in the yield of small-scale farmers in the region.

Table 3.11: Symmetric measures

\begin{tabular}{|l|l|l|l|}
\hline \multicolumn{2}{|c|}{} & Value & Approx. Sig. \\
\hline Nominal by Nominal & Phi & .208 & .001 \\
\cline { 2 - 4 } & Cramer's V & .208 & .001 \\
\hline N of Valid Cases & 317 & \\
\hline a. Not assuming the null hypothesis. \\
\hline
\end{tabular}

\section{Descriptive Statistics on Agricultural Extension Services} Attendance to Agricultural Field Days

The researcher sought to know if the farmers have been attending agricultural field day actively, from analysis, majority of the farmers have not been attending the agricultural field days by a proportion of $64.4 \%$.

Table 3.12: Attendance Agricultural Field Days

\begin{tabular}{|c|l|l|l|l|l|}
\hline \multicolumn{2}{|c|}{} & Frequency & Percent & Valid Percent & Cumulative Percent \\
\hline Valid & & 3 & .9 & .9 & .9 \\
\cline { 2 - 6 } & Don't know & 1 & .3 & .3 & 1.3 \\
\cline { 2 - 6 } & No & 204 & 64.4 & 64.4 & 65.6 \\
\cline { 2 - 6 } & Yes & 109 & 34.4 & 34.4 & 100.0 \\
\cline { 2 - 6 } & Total & 317 & 100.0 & 100.0 & \\
\hline
\end{tabular}

\section{Frequency of Visit by Agricultural Service Providers}

The research findings reflected that majority of the agricultural service providers visits the farmers once a month with a proportion of $35.5 \%$.

Table 3.13: Frequency of Farm Visit

\begin{tabular}{|l|l|l|l|l|l|}
\hline \multicolumn{2}{|c|}{} & Frequency & Percent & Valid Percent & Cumulative Percent \\
\hline Valid & & 6 & 1.9 & 1.9 & 1.9 \\
\cline { 2 - 6 } & None at all & 56 & 17.7 & 17.7 & 19.6 \\
\cline { 2 - 6 } & Once a month & 111 & 35.0 & 35.0 & 54.6 \\
\cline { 2 - 6 } & Rarely & 66 & 20.8 & 20.8 & 75.4 \\
\cline { 2 - 6 } & Weekly & 78 & 24.6 & 24.6 & 100.0 \\
\cline { 2 - 6 } & Total & 317 & 100.0 & 100.0 & \\
\hline
\end{tabular}

\section{DisCUSSION}

The constant coefficient has a negative influence on the agricultural productivity implying that keeping other variables of interest a constant, the productivity level will decrease by 3.268. Subsidized fertilizer has a positive influence on agricultural productivity as the logistic regression suggests that keeping other variables a constant, for every unit increase in subsidized fertilizer there is a 24.471 increase in productivity. For every unit increase of subsidized seed while keeping other variables a constant, productivity increases by 1.030. Subsidized farm logistic has the smallest influence on productivity as it only leads to a 0.982 increase in productivity.

The significance level has P-values 0.002 for subsidized fertilizer, 0.012 for the subsidized seeds, 0.019 for farm logistics and 0.000 for the constant coefficient which they are all less than the standard P-value 0.025 implying that all the coefficients are statistically significant and thus they have influence on agricultural productivity.

Table 4.1: Logistic regression output

\begin{tabular}{|c|c|c|c|c|c|c|c|}
\hline \multicolumn{8}{|c|}{ Variables in the Equation } \\
\hline & & $\mathrm{B}$ & S.E. & Wald & df & Sig. & $\operatorname{Exp}(B)$ \\
\hline \multirow[t]{4}{*}{ Step $1^{\mathrm{a}}$} & Subsidized_fertilizer(1) & 24.471 & 402.970 & .000 & 1 & .002 & .000 \\
\hline & Subsidized_seeds (1) & 1.030 & .481 & 4.577 & 1 & .012 & .357 \\
\hline & Farm_logistics(1) & .982 & .419 & 5.499 & 1 & .019 & .374 \\
\hline & Constant & -3.268 & .404 & 65.511 & 1 & .000 & 26.263 \\
\hline
\end{tabular}


From the logistic regression, a classification table was obtained. The classification table contains predicted values and the observed values as shown in Table 5.2 below. The accuracy is 90.36 implying that the independent variables; subsidized fertilizer, subsidized seeds and farm logistics account for $90.36 \%$ of the improved yield performance in agricultural productivity among small-scale farmers.

Table 4.2: Classification table for model performance

\begin{tabular}{|c|c|c|c|c|c|}
\hline \multicolumn{3}{|c|}{ Observed } & \multicolumn{3}{|c|}{ Predicted } \\
\hline & & & \multicolumn{2}{|c|}{ improved_yield } & \multirow[t]{2}{*}{ Percentage Correct } \\
\hline & & & 0 & 1 & \\
\hline \multirow[t]{3}{*}{ Step 0} & \multirow[t]{2}{*}{ improved_yield } & 0 & 23 & 20 & .0 \\
\hline & & 1 & 1 & 274 & 100.0 \\
\hline & \multicolumn{2}{|c|}{ Overall Percentage } & & & 90.36 \\
\hline \multicolumn{6}{|c|}{ a. Constant is included in the model. } \\
\hline \multicolumn{6}{|c|}{ b. The cut value is .500} \\
\hline
\end{tabular}

\section{CONCLUSION}

Agricultural subsidies accelerate the use of quality fertilizer and seeds and also minimizes time spent in field preparation thereby promoting overall agricultural production. The use of fertilizer, seed subsidies and use of farm machinery at a subsidized cost were found to significantly improve crop production ( $\mathrm{p}$-value $<0.0001$ ). This positive effect is consistent with the findings from Davidova et al., [30] where subsidized fertilizer was found to have positive effects on the kilocalories available per capita per day. Therefore, subsidized farm inputs will encourage more farmers to use it which will greatly increase farm produce of the small-scale farmers [31].

\section{REFERENCES}

1. Rogers KM, Thomas M, Johnston PG, Longely DB. Interferon- $\gamma$-mediated modulation of chemotherapy-induced cell death in breast cancer. 2006.

2. Dorward, A. Rethinking Agricultural Input Subsidy Programmes in a Changing World [Prepared for FAO]. 2009.

3. Morris M, Kelly VA, Kopicki R, Byerlee D. Fertilizer use in African agriculture. Directions in Development: Agriculture and Development. 39037. World Bank, Washington, D.C.USA. 2007. Availableat:https://openknowledge.worldbank.org/bitstream/handle/10986/6650/390370AFR0Fert101OFFICIAL0 USE0ONLY1.pdf?sequence=123 The Campbell Collaboration. www.campbellcollaboration.org

4. FAO. STATISTICS. Maize Production Trend in Kenya 1960-2011. 2013.

5. Crawford JR, Garthwaite PH. Evaluation of criteria for classical dissociations in single-case studies by Monte Carlo simulation. Neuropsychology. 2005 Sep;19(5):664.

6. Minde IJ, Jayne TS, Crawford EW, Ariga J, Govereh J. Promoting fertilizer use in Africa: current issues and empirical evidence from Malawi, Zambia, and Kenya (No. 1093-2016-88032); 2008.

7. Demir S, Mirshahi N, Tiba MH, Draucker G, Ward K, Hobson R, Najarian K. Image processing and machine learning for diagnostic analysis of microcirculation. In2009 ICME International Conference on Complex Medical Engineering 2009 Apr 9 (pp. 1-5). IEEE.

8. Banful AB. Market-smart? Lessons from the 2008 and 2009 Fertilizer Subsidy Programs in Ghana'. Ghana Strategy Support Program. 2010.

9. Duflo E, Dupas P, Kremer M. Education and fertility: Experimental evidence from Kenya. Unpublished Manuscript, J-PAL/MIT. Cambridge, MA. 2010 Feb 16.

10. Denning DW, O'Driscoll BR, Powell G, Chew F, Atherton GT, Vyas A, Miles J, Morris J, Niven RM. Randomized controlled trial of oral antifungal treatment for severe asthma with fungal sensitization: The Fungal Asthma Sensitization Trial (FAST) study. American journal of respiratory and critical care medicine. 2009 Jan 1;179(1):11 8.

11. Otunge D, Muchiri N, Wachoro G, Gethi J, Agili G. Reducing maize insecurity in Kenya: the WEMA project, AATF and KARI, Kenya. 2010.

12. Uaiene RN, Arndt C, Masters WA. Determinant of Agricultural Technology Adoption in Mozambique; Ministry of Planning, Mozabique. 2009.

13. Komárek M, Čadková E, Chrastný V, Bordas F, Bollinger JC. Contamination of vineyard soils with fungicides: a review of environmental and toxicological aspects. Environment international. 2010 Jan 1;36(1):138-51.

14. MOA. Economic Review of Agriculture, 2013. Ministry of Agriculture, Livestock and Fisheries: Nairobi. 2013.

15. US Department of agriculture. Kenya Corn Domestic Consumption per Year. 2014.

16. Oso WY, Onen D. A General Guide Line to Writing Research Proposal and Report. A Handbook for the Beginning Researchers. Makerere University, Kampala. 2008.

17. Shuttleworth WJ. Evapotranspiration measurement methods. Southwest Hydrology. 2008;7(1):22-3. 
18. Koul HL. Minimum distance estimation and goodness-of-fit tests in first-order autoregression. The Annals of Statistics. 1986 Sep 1:1194-213.

19. Kasomo D. Guidance and counseling handbook for universities and colleges. Eldoret: Zapf Chancery. 2007.

20. Kathuri NJ, Pals DA. Introduction to Educational Research. Njoro, Kenya: Educational Media Centre, Egerton University ACTS Press. 1993.

21. Miles MB, Huberman AM. Qualitative data analysis: An expanded sourcebook. sage; 1994 Jan 12.

22. Savadogo P, Sanou L, Dayamba SD, Bognounou F, Thiombiano A. Relationships between soil seed banks and above-ground vegetation along a disturbance gradient in the W National Park trans-boundary biosphere reserve, West Africa. Journal of Plant Ecology. 2017 Apr 1;10(2):349-63.

23. Darko FA, Ricker-Gilbert J. Economic efficiency and subsidized farm inputs: evidence from Malawi maize farmers. 2013.

24. Dorward A, Chirwa E. The Malawi agricultural input subsidy programme: 2005/06 to 2008/09. International journal of agricultural sustainability, 2011;9(1):232-247.

25. Kansiime MK, van Asten P, Sneyers K. Farm diversity and resource use efficiency: Targeting agricultural policy interventions in East Africa farming systems. NJAS-Wageningen Journal of Life Sciences, 2018;85:32-41.

26. Dorward A, Chirwa E, Boughton D, Crawford E, Jayne T, Slater R, ... Tsoka M. Towards 'smart'subsidies in agriculture? Lessons in recent experience in Malawi. Natural resources perspectives, 2008; (116).

27. Abubakari F, Abubakari F. Effects of Awareness of Fertilizer Subsidy on the Yield of Crops among Rural Farmers in Ghana. International Journal of Agricultural Science, Research and Technology in Extension and Education Systems, 2014; 4(3):123-126.

28. Siele NK. Factors Influencing Access to Subsidized Fertilizer By Maize Farmers In Kesses Sub-County, Uasin Gishu County, Kenya (Doctoral dissertation, University of Nairobi). 2018.

29. Willy RW, Hoglund LT, Barton CJ, Bolgla LA, Scalzitti DA, Logerstedt DS, Lynch AD, Snyder-Mackler L, McDonough CM, Altman R, Beattie P. Patellofemoral pain: clinical practice guidelines linked to the international classification of functioning, disability and health from the academy of orthopaedic physical therapy of the American physical therapy association. Journal of Orthopaedic \& Sports Physical Therapy. 2019 Sep;49(9):CPG1 95.

30. Davidová T, Dostál T, David V, Strauss P. Determining the protective effect of agricultural crops on the soil erosion process using a field rainfall simulator. Plant, Soil and Environment. 2015.

Jayne TS, Sitko NJ, Mason NM, Skole D. Input subsidy programs and climate smart agriculture: Current realities and future potential. In Climate Smart Agriculture. 2018; (pp. 251-273). Springer, Cham.

Citation: E. Ambajo et al (2021). Influence of Farm Inputs Subsidy on Agricultural Yields by Small Scale Farmers in Alego Usonga Sub-County, Siaya County, Kenya. South Asian Res J Agri Fish, 3(2), 26-33. 